\title{
Rancang Bangun Game Simulasi Pemrograman Berbasis Obyek (PBO) Sebagai Media Pembelajaran Mahasiswa Teknik Informatika Universitas Muhammadiyah Sidoarjo
}

\author{
Cindy Taurusta ${ }^{1}$, Yulian Findawati ${ }^{2}$ \\ ${ }^{1}$ Program Studi Informatika, Fakultas Teknik, Universitas Muhaammaddiyah Sidoarjo \\ e-mail:cindytaurusta@umsida.ac.id \\ ${ }^{2}$ Program Studi Informatika, Fakultas Teknik, Universitas Muhaammaddiyah Sidoarjo \\ e-mail: yulianfindawati@umsida.ac.id
}

\begin{abstract}
Abstrak
Kemajuan teknologi yang semakin pesat seiring dengan meningkatnya kebutuhan akan lulusan Teknik Informatika di Perguruan Tinggi. Banyak perusahaan dan dunia bisnis saat ini membutuhkan lulusan yang mampu bersaing dalam hal pemrograman. Dan pemrograman yang paling dominan yang harus dapat dikuasi oleh lulusan Teknik Informatika yaitu Pemrograman Berbasis Obyek (PBO) atau biasa dikenal dengan Pemrograman Java. Dimana pemrograman ini adalah pemrograman yang dapat menghasilkan berbagai macam aplikasi, baik aplikasi di Personal Computer (PC) maupun di mobile. Namun berdasarkan analisa yang dilakukan oleh peneltiti saat mengajar mata kuliah pemrograman berbasis obyek (PBO) di Teknik Informatika Fakultas Teknik Universitas Muhammadiyah Sidoarjo, ditemukan hasil bahwa masih banyak mahasiswa yang masih kesulitan mempelajari mata kuliah ini, bila hanya diajarkan melalui teori tanpa adanya praktek langsung. Sehingga agar mahasiswa tertarik untuk mempelajari mata kuliah ini lebih lanjut dan pembelajarannya tidak hanya melalui teori, pembelajaran yang menyenangkan akan peneliti lakukan dengan membuat Rancang Bangun Game Simulasi Pemrograman Berbasis Obyek (PBO) Sebagai Media Pembelajaran Mahasiswa Teknik Informatika Universitas Muhammadiyah Sidoarjo. Game ini akan berisi beberapa level pembelajaran yang dikemas dengan animasi. Dimana pemainnya yaitu mahasiswa tidak hanya mendapatkan pembelajaran tentang apa saja komponen yang dibutuhkan dalam memprogram Java, namun juga langkah - langkah memprogram Java dengan mudah yang disuguhkan dengan animasi yang menarik. Tidak hanya rasa penasaran dan keseruan dalam bermain tetapi memahami dan membuat program menjadi lebih mudah. Tujuan dibuatnya Game simulasi pembelajaran ini agar dapat membantu Mahasiswa Teknik Informatika Universitas Muhammadiyah Sidoarjo dalam memahami, menyukai, dan mampu membuat program berbasis obyek atau Java sehingga meningkatkan mutu dan daya saing Mahasiswa Teknik Informatika Universitas Muhammadiyah Sidoarjo di dunia kerja. Dan kedepannya, peneliti akan melakukan survey untuk membuktikan efek dan hasil yang didapatkan setelah melakukan pembelajaran melalui game simulasi.
\end{abstract}

Kata Kunci : Game Simulasi, Animasi, Mahasiswa IT, Pemrograman Berbasis Obyek, Java 
Rancang Bangun Game Simulasi Pemrograman Berbasis Obyek (PBO) Sebagai Media

Pembelajaran Mahasiswa Teknik Informatika Universitas Muhammadiyah Sidoarjo

\begin{abstract}
Abstrak
Technological progress is increasing rapidly along with the increasing need for graduates of Informatics Engineering in Higher Education. Many companies and businesses today require graduates who can compete in terms of programming. And the most dominant programming that must be mastered by the graduates of Informatics Engineering is Object-Based Programming (PBO) or commonly known as Java Programming. Where this programming is programming that can generate various applications, both applications in Personal Computer (PC) and in mobile. However, based on analysis conducted by the researcher when teaching objectbased programming program (PBO) in Informatics Engineering Faculty of Engineering Muhammadiyah University of Sidoarjo, found the result that there are still many students who still difficulty studying this course, if only taught through theory without any direct practice. So that students interested in studying this subject further and learning not only through theory, a fun learning will researchers do by making the Design of Object-Based Programming Simulation Game (PBO) As Media Student Learning Informatics University of Muhammadiyah Sidoarjo. This game will contain several learning levels packed with animation. Where players are students not only get learning about what components are required in programming Java, but also steps - steps programming Java easily presented with an interesting animation. Not only the curiosity and excitement in playing but understanding and making the program easier. The purpose of making this learning simulation game in order to help Student of Informatics Engineering Muhammadiyah University of Sidoarjo in understanding, likes, and able to make object-based program or Java so as to improve the quality and competitiveness of Informatics Engineering Student University of Muhammadiyah Sidoarjo in the world of work. And in the future, researchers will conduct a survey to prove the effects and results obtained after learning through simulation games.
\end{abstract}

Keywords: Simulation Game, Animation, IT Student, Object-Based Programming, Java

\title{
Pendahuluan
}

Kebutuhan akan lulusan Teknik Informatika yang berkompeten terutama dalam pemrograman semakin bertambah namun tidak diimbangi dengan kompetensi mahasiswa itu sendiri dalam penguasaan pemrograman. Masih banyak lulusan Informatika yang tidak bekerja dibidangnya bahkan sama sekali tidak menguasai pemrograman. Pemrograman dalam kurikulum Strata-1 (S1) Teknik Informatika Universitas Muhammadiyah Sidoarjo yaitu mulai dari Algoritma pemrograman yang didapat di semester 1, kemudian Algoritma dan Struktur Data di semester 3, dan Pemrograman Berbasis Web serta Pemrograman Berbasis Objek di semester 5. Peneliti mencoba menelusuri penyebab kurang menguasai dan kurangnya minat mahasiswa Informatika terhadap pemrograman. Dan peneliti 